\title{
Waste Management Practices of Construction Companies at the Airport Hills and Sakumono Areas in Accra, Ghana
}

\author{
Donald N. Amuna ${ }^{1}$, Zarouk A. Imoro ${ }^{1,2}$, Samuel J. Cobbina ${ }^{1}$ and Samuel A. Ofori ${ }^{1,3^{*}}$ \\ ${ }^{1}$ Department of Environment and Sustainability Sciences, Faculty of Natural Resources and Environment, \\ University for Development Studies, Tamale, Ghana \\ ${ }^{2}$ Department of Environment, Water and Waste Engineering, School of Engineering, University for Development \\ Studies, Tamale, Ghana \\ ${ }^{3}$ Département de Biologie des Organismes, Faculté des Sciences, Université Libre de Bruxelles, Brussels, Belgium \\ *Corresponding Author: ofori496@gmail.com \\ DOI: $10.4314 /$ rjeste.v4i1.14 \\ https://dx.doi.org/10.4314/rjeste.v4i1.14
}

\begin{abstract}
Waste generated in the construction industry is a major environmental problem but its research is rather limited. Thus, this research was conducted to assess the waste disposal practices of construction companies at the Airport Hills and Sakumono areas in Accra, Ghana. These areas were chosen because of the increasing and fast development of housing projects there. A convenience sampling technique was used in choosing the companies to achieve the research goal. Questionnaires and field observations were used to gather information about the construction companies and their waste management practices. Forty construction companies were identified in both study areas. Majority of the companies recorded a total of 60-80 cubic meters of material waste per month. Eleven companies stated amounts of between USD 250 - 350 as cost of material waste management per month. Several reusable materials were identified at construction sites. Twenty-six companies practised sorting and recovery of waste before final disposal. It was revealed that there was no statistically significant relationship between the educational levels of waste management teams of the construction companies and their practice of proper waste management methods. A significant relationship however existed between the educational level of waste management teams and their use of waste management plans. It is recommended that waste management training programmes are developed by the Environmental Protection Agency of Ghana for construction companies to curb the problem of poor construction waste management.
\end{abstract}


Rwanda Journal of Engineering, Science, Technology and Environment, Volume 4, Issue 1, June 2021

eISSN: 2617-233X | print ISSN: 2617-2321

Keywords: Construction companies, construction waste, waste management practices, waste management plan

\subsection{Introduction}

The construction industry forms a major part of the world's economy rolling out and promoting projects unabatedly. The living conditions, social well-being and health of the public is gradually being affected by the development of the construction sector (Hasmori et al., 2020). Construction projects are necessities for new facilities, they are means to reduce unemployment and are required for the development of the world. Nevertheless, each project produces some level of waste which can increase project cost and add to environmental pollution (Shant et al., 2014). Deteriorating environmental quality is a global discussion to which the construction industry features in the major headlines.

Ametepey and Ansah (2009) reported that the quest for urban development which includes the construction of buildings has resulted in resource depletion and ecosystem destruction. This has to some extent put the construction industry under the spotlight since its activities' significant impact on the environment cannot be over-emphasised (Oke et al., 2019).

Research has shown that approximately $40 \%$ of the waste generated worldwide originates from the construction industry (Holm, 1998) and this forms a major portion of the solid waste discarded in landfills around the world. For instance, in the USA construction waste takes up approximately 29\% of landfill space (Bossink and Brouwers, 1996) whiles in Australia it consumes about 44\% of landfills space by mass (McDonald and Smithers, 1998).

It is important that construction companies use integrated strategies to manage waste. That is the use of a multitude of interconnected processes, such as gathering and collection, site-sorting, transportation, treatment, recycling, and appropriate disposal (Al Sabbagh et al., 2012). Construction waste is generally defined as the unexploited or unwanted materials or products emanating from construction activities during the pre-construction, construction and postconstruction phase. These may also include waste produced from renovation and demolition works. Construction waste streams consist mainly of unused concrete, wood, metal, broken tiles, 
bricks and pieces of electrical wires (Hasmori et al., 2020). These wastes are bulky and consume a lot of space either in bins, in the open or landfills.

Presently, awareness of efficient waste management in the construction industry of Ghana is low. This is proven by the poor waste disposal practices of some companies in the country. In Ghana, it is not uncommon to see huge piles of construction waste on the shoulders of roads. Such stacks of wastes choke drains and often cause flooding of roads and low-lying areas (Job and Wilson, 2013). There is therefore a need to sensitize the government and other stakeholders on this worrying situation and to do this, scientific data must be provided to support arguments. Thus, this current research was conducted to provide information on the waste management practices of some construction companies in the Airport Hills and Sakumono residential areas in the Greater Accra region of Ghana.

\subsection{Materials and methods}

\subsection{Study area}

The study areas, Airport hills and Sakumono, are respectively located in the Accra Metropolitan Assembly (AMA) and the Tema Metropolitan Assembly (TMA) of the Greater Accra Region of Ghana. The Airport hills is a new and fast-developing area undoubtedly the highest sort-after place in real estate in Ghana. It is a gated community with 24/7 security and allows only reputable tenants in the neighbourhood. Availability of electricity and a constant supply of water with overhead/underground storage tanks are assured. There are construction activities ongoing in this area which includes major real estate construction companies. Sakumuno is a small town in the Nugcity at Tema Metropolis with an elevation of $71 \mathrm{~m}$. It also attracts relatively large developmental projects yearly. The two study areas (Airport hills and Sakumono) were chosen because of the increasing and fast development of housing projects there.

\subsection{Data collection}

Forty (40) active construction sites and for that matter, companies were sampled in this study. Due to the nature of the subject matter of this research, convenience sampling techniques were used in choosing the study areas and companies in order to achieve the research goal. The main data 
collection technique and instrument used for the study were personal observations and questionnaire administration, respectively. Personal observations were employed in gathering vital ground data including structure type, nature of the construction environment, on-site waste disposal and waste separation. Questionnaires with closed-ended questions were administered to solicit information from a qualified professional (engineer, supervisor, architect, environmental officer) who represented the company in each project site. The questions were structured into three categories: (a) Type and quantity of waste generated (b) construction site waste disposal practice and (c) resource recovery and reuse.

\subsection{Results}

\subsection{Quantity of material waste generated at project sites}

The major waste materials that were identified at the construction sites included pieces of wood, metals, plastics, electric cables, roofing sheets, unused concrete, and broken blocks. Figure 1 provides information about the amount of material waste generated in a month by the construction companies. Out of the 40 companies, only one generated a volume of waste ranging between 3040 cubic meters per month. An appreciable number of the companies (17 out of 40,42.5\%) recorded a total of 60-80 cubic meters of material waste per month.

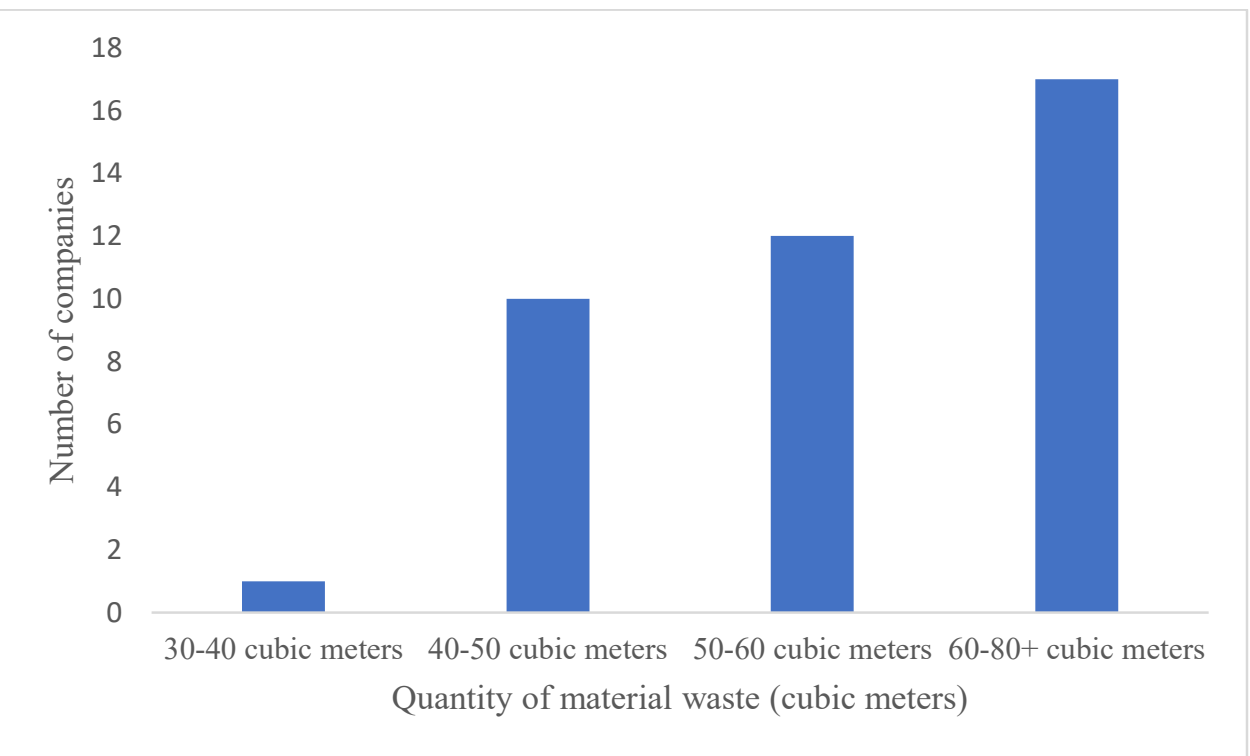

Figure 1: Quantity of material waste generated by construction companies 


\subsection{Material waste management practices}

A number of waste management practices were evaluated to assess how construction companies took care of their material waste. Out of a total of 40 companies, 26 practised sorting and recovery before final disposal, 13 disposed of their waste at waste dump sites, and the remaining (1) left their waste at the site (Figure 2).

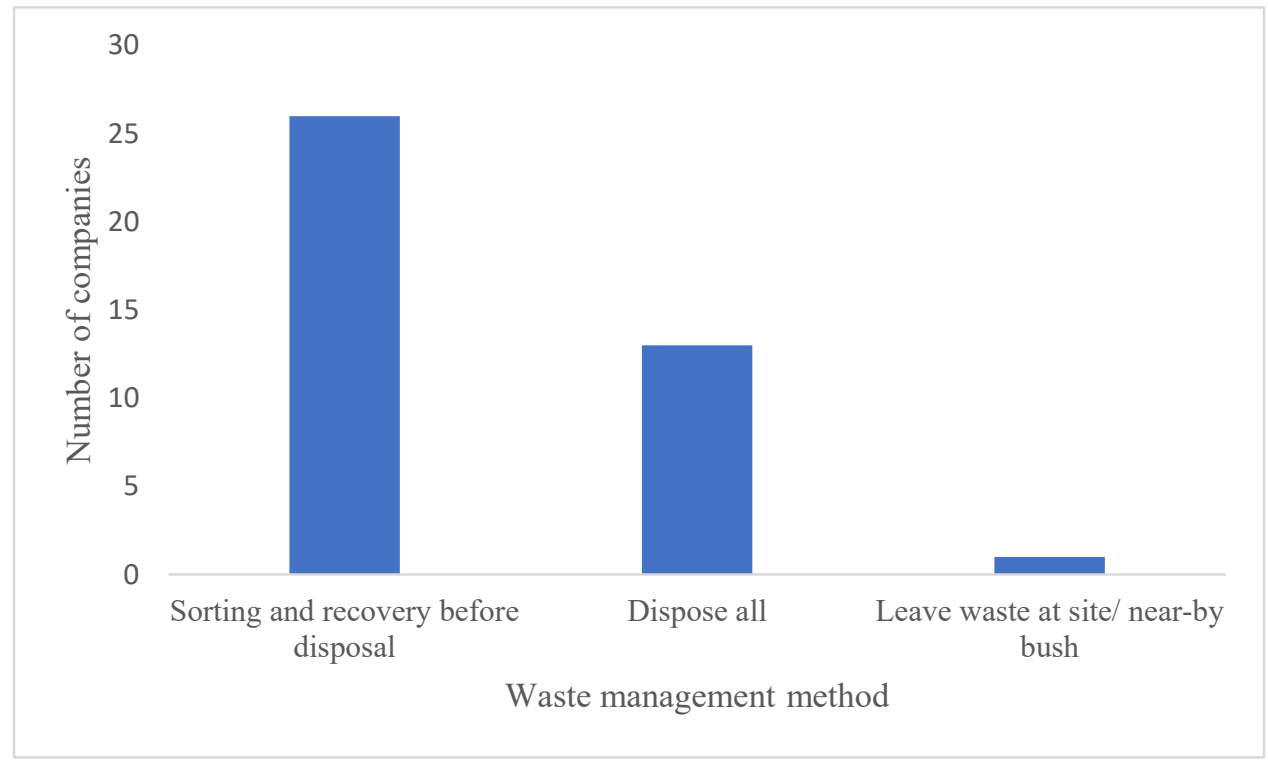

Figure 2: Waste management methods practised by construction companies

\subsection{Estimated amount of money spent on material waste management}

Figure 3 illustrates the estimated amount of money used in a month by the construction companies in managing their material waste. Out of the 40 companies that were recorded, 27 were able to provide an estimate of the amount of money used for material waste management. Several (41\%) of the companies reported they spent between USD 250 and 350 as the cost for waste management in a month. Only two companies reported that they spent money in the range of USD 170-250 and USD 85-171 in a month for waste management. Five (5) companies reported that they spent USD 430 on waste management. 


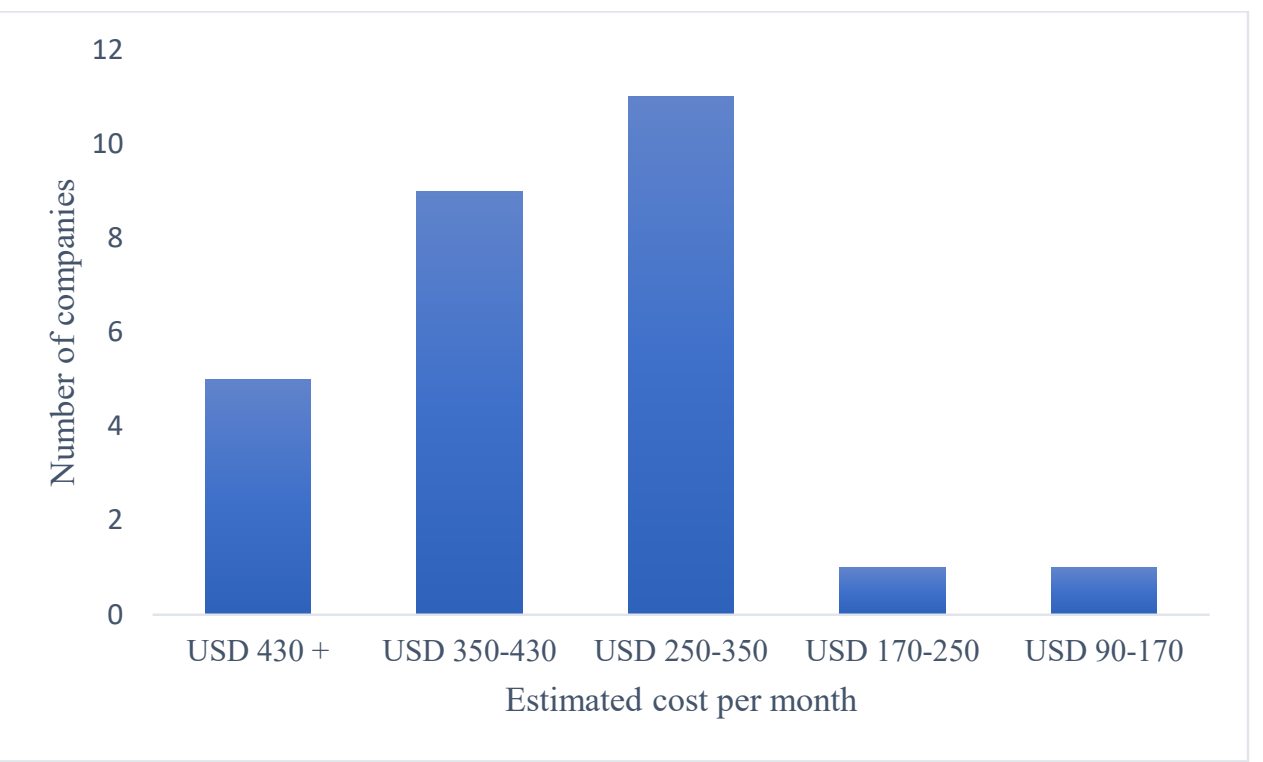

Figure 3: Estimated cost of material waste management per month by construction companies

\subsection{Relationship between the level of education of waste management team and waste disposal practices}

It was identified that 14 of the construction companies had professionally trained waste management teams and three (3) had no trained-waste management teams at all. Out of the 14 companies which had professionally trained waste management teams, nine (9) of them practice sorting and recovery of waste before final disposal, whereas five (5) did not practice waste sorting nor recovery. There was no statistically significant relationship $(\mathrm{p}>0.05)$ between the level of education of waste management teams and the waste management methods they used (Table 1).

Table 1: Relationship between the level of education of waste management team and their waste management methods

\begin{tabular}{|c|c|c|c|c|c|c|}
\hline \multirow{2}{*}{$\begin{array}{l}\text { Level of training for } \\
\text { waste } \quad \text { management }\end{array}$} & \multicolumn{4}{|c|}{ Waste management method } & \multirow[t]{2}{*}{ Total } & \multirow[t]{2}{*}{ P-value } \\
\hline & $\begin{array}{l}\text { Sorting } \\
\text { recovery } \\
\text { disposal }\end{array}$ & $\begin{array}{r}\text { and } \\
\text { before }\end{array}$ & $\begin{array}{l}\text { Dispose of } \\
\text { all }\end{array}$ & $\begin{array}{l}\text { Leave waste } \\
\text { at } \\
\text { site/nearby } \\
\text { bush }\end{array}$ & & \\
\hline Professionally trained & 9 & & 5 & 0 & 14 & 0.767 \\
\hline
\end{tabular}


Rwanda Journal of Engineering, Science, Technology and Environment, Volume 4, Issue 1, June 2021

eISSN: 2617-233X | print ISSN: 2617-2321

\begin{tabular}{lllll}
\hline Very trained & 7 & 2 & 0 & 9 \\
Averagely trained & 4 & 3 & 1 & 8 \\
Less trained & 4 & 2 & 0 & 6 \\
Not trained & 2 & 1 & 0 & 3 \\
Total & 26 & 13 & 1 & 40 \\
\hline
\end{tabular}

3.5 The relationship between the educational levels of waste management teams and their use of a waste management plan

An assessment was conducted to know if there existed a relationship between the educational level of the waste management teams and their use of waste management plans. Interestingly 18 out of the 40 construction companies made use of waste management plans while 15 of the remaining did not use plans though they had received some level of training in waste management. The remaining seven (7) construction companies were ignorant about waste management plans, and thus did not make use of one. There was a statistically significant $(\mathrm{p}<0.05)$ relationship between the level of education of the waste management teams and their use of waste management plans.

Table 2: Relationship between the level of education of waste management teams and their use of waste management plans

\begin{tabular}{|c|c|c|c|c|c|c|c|}
\hline \multirow{2}{*}{$\begin{array}{l}\text { Use of a waste } \\
\text { management } \\
\text { plan }\end{array}$} & \multicolumn{5}{|c|}{ Educational/training levels of waste management teams } & \multirow{2}{*}{ Total } & \multirow{2}{*}{$\begin{array}{l}\text { P- } \\
\text { value }\end{array}$} \\
\hline & $\begin{array}{l}\text { Professionally } \\
\text { trained }\end{array}$ & $\begin{array}{l}\text { Very } \\
\text { trained }\end{array}$ & $\begin{array}{l}\text { Averagely } \\
\text { trained }\end{array}$ & $\begin{array}{l}\text { Less } \\
\text { trained }\end{array}$ & $\begin{array}{l}\text { Not } \\
\text { trained }\end{array}$ & & \\
\hline Yes & 11 & 3 & 4 & 0 & 0 & 18 & 0.038 \\
\hline No & 4 & 4 & 3 & 3 & 1 & 15 & \\
\hline No knowledge & 0 & 2 & 1 & 2 & 2 & 7 & \\
\hline Total & 15 & 9 & 8 & 5 & 3 & 40 & \\
\hline
\end{tabular}

\subsection{Reusable materials in construction waste}


The construction industry has waste materials that can be recovered for reuse and recycling. Table 3 presents information on reusable materials identified at the construction sites.

Table 3: Reusable materials from construction waste

\begin{tabular}{ll}
\hline Waste materials & Materials identified \\
\hline Wood waste & Bamboo, papers \\
Plastics waste & PVC pipes \\
Sand waste & Cement, sand \\
Metal waste & Iron rods, roofing sheets, electric cables \\
\hline
\end{tabular}

\subsection{Discussion}

\subsection{Quantity of material waste generated in volumes at project sites}

Construction waste represents a major portion of the worldwide solid waste reaching landfill sites (de Souza et al., 2020). With $42.5 \%$ of the construction companies producing the largest quantity of material waste (60-80 cubic meters) per month, there is a great need for concern. First of all, these materials waste which includes wood, plastics, metals, unused concrete and mortar are estimated to be of high environmental and economic costs considering their production and supply chains. Moreover, considering the increasing and fast development of housing projects in the study area, vis-à-vis the quantity of waste generated in a month, the yearly quantity of waste generated will be grave. What happens to these high quantities of waste generated? Not surprisingly, the volumes of construction waste generated continues to increase across the world. For instance, Asgari et al. (2017) estimated that the quantity of construction waste generated in Tehran was about 16,529,210 cubic meters per year of which mortar (mixed sand and cement) and concrete was the highest contributor to the large volume of waste generated.

\subsection{Evaluation of material waste management practices at construction sites}

With the majority $(65 \%)$ of the construction companies practising sorting and recovery of their material waste before final disposal, there was an indication of some level of proper waste 
management practice existing among the companies. It has been established that construction companies who practise waste sorting and recovery enjoy benefits such as reduced demand for new resources, reduction in transport and production energy cost and the use of material waste which would otherwise be lost to landfill sites (Tam and Lu, 2016). However, with $32.5 \%$ of the remaining construction companies disposing of all the generated material waste into landfills is worrying. Looking at the nature of construction waste, their final destination in landfill sites with low potential of waste recovery would lead to these landfill sites becoming filled more quickly. A similar situation in a country like Malaysia has led to about 113 out of 289 landfills and dumpsites becoming un-operational (Hasmori et al., 2020). It was saddening to find out that one of the construction companies did not collect waste generated on-site. Ikau et al. (2016) reported a similar observation in Malaysia where contractors did not dispose of waste generated on-site. This situation poses an environmental problem, especially where construction sites are at high lands and water sources/drains are at lowlands. The repercussions could be the occurrence of flooding events due to choked drainage systems or the pollution of water sources.

\subsection{Amount of money spent on managing material waste}

In the context of the study area and the high class of construction companies that were involved in this study, the cost of managing material waste could be said to be affordable. Especially that the majority of the construction companies paid an amount of USD 250-350 in a month for waste management. As suggested by Tam and Lu (2016), the low fees paid for waste management could be due to the practice of waste sorting and recovery of valuable materials for reuse.

\subsection{Level of education and waste management practices}

In order to understand how a majority of the construction companies were able to properly manage their material wastes, their educational/training levels were assessed. It is reported that the method of waste disposal practised by a construction company may depend on the level of education or training gained by its waste management team (Hittini and Shibeika, 2019; Hasmori et al., 2020). Noted as contrasting outcomes, five of the construction companies with professionally trained waste management teams did practise disposal, while 6 of the construction companies with less or not trained waste management teams did practise sorting and recovery of their material waste before final disposal. This outcome was reiterated by the statistically not significant relationship 
$(p>0.05)$ between the education of the waste management team and their choice of waste management methods. According to Memon et al. (2015), the main factors that could lead to large waste generation at construction sites include lack of waste management strategy, poor layout of construction sites, and poor qualification of managers of construction projects. This indicates that one's level of education alone is not enough to determine the kind of waste management practice(s) the individual or a team may use (Hittini and Shibeika, 2019). However, the impact of education on the use of waste management plans was profound and this should be encouraged.

\subsection{Reusable materials in construction waste}

Material waste generation at construction sites is unavoidable and construction companies have the potential to recover and reuse most of them. The fact that most of the construction companies in this study saw the need to recover some materials for reuse in other projects was a positive sign of waste reduction and consequently, the sparing of landfill space. It is important to note that while some construction companies made use of these reusable materials (as proven by their sorting and recovery of construction waste), others did not find any potential in them. Companies that disregard these reusable materials may do so either due to their ignorance (i.e., low educational level on waste management) of the benefits of reusable materials, or limited time needed to collect these reusable materials, or negligence since they can afford new materials or they have a higher deposit of these materials (Hobbs and Adams, 2017). The reuse of these materials will however go a long way to save energy, time, and financial cost for the construction companies.

\section{Conclusion}

The quantities of waste generated at the construction sites were large enough to raise concerns. However, some of these wastes were reusable. Also, even though education was related to the use of waste management plans, it, however, did not guarantee the practice of recommended waste management methods by the construction companies. With a majority of the companies paying an amount of USD 250-350 in a month for waste management, there lies a great potential of reduced cost if construction companies practise waste recovery and reuse. It is recommended that training programmes and policies are developed by the Environmental Protection Agency of Ghana to help 
promote the practice of recommended waste management methods by construction companies. A further study is expected to be done to understand the attitude of construction companies in Ghana towards sustainable design and construction or green building as a way of reducing construction waste generation.

\section{Acknowledgement}

The authors are grateful to the construction companies and their workers who voluntarily took part in this study. 
Rwanda Journal of Engineering, Science, Technology and Environment, Volume 4, Issue 1, June 2021

eISSN: 2617-233X | print ISSN: 2617-2321

\section{References}

Al Sabbagh K.M, Costas A.V, David C.W, Christopher R.C. (2012). Resource management performance in Bahrain: a systematic analysis of municipal waste management, secondary material flows and organizational aspects, SAGE publication company, 2(34):72-78

Ametepey, S.O., Ansah, S.K. (2015). Impacts of construction activities on the environment: The 246 case of Ghana. Journal of environment and earth science, 5(3),18-26

Asgari, A., Ghorbanian, T., Yousefi, N., Dadashzadeh, D., Khalili, F., Bagheri, A., Raei, M., Mahvi, A. H. (2017). Quality and quantity of construction and demolition waste in Tehran. Journal of Environmental Health Science and Engineering, 15(1), 1-8 https://doi.org/10.1186/s40201-017-0276-0

Bossink, B. A. G., Brouwers, H. J. H. (1996). 'Construction waste: quantification \& source evaluation', Construction engineering \& management, ASCE 122(1), 55-60

Dajadian, S.A., Koch, D.C. (2014).Waste management models and their applications on construction sites. International Journal of Construction Engineering and Management, 3(3): 91-98

de Souza, J. M. de, Rudnick, R. C., Lukiantchuki, J. A. (2020). Evaluation of the incorporation of construction waste $(\mathrm{CW})$ for the stabilization of soil-cement mixtures. Ambiente Construído, 20(4), 261-280 https://doi.org/10.1590/s1678-86212020000400471

Fikri Hasmori, M., Faizul Md Zin, A., Nagapan, S., Deraman, R., Abas, N., Yunus, R., Klufallah, M. (2020). The on-site waste minimization practices for construction waste. IOP Conference Series: Materials Science and Engineering, 713(1) https://doi.org/10.1088/1757$\underline{899 X / 713 / 1 / 012038}$

Hassan, S. H., Aziz, H. A., Daud, N. M., Keria, R., Noor, S. M., Johari, I., Shah, S. M. R. (2018). The methods of waste quantification in the construction sites (A review). AIP Conference Proceedings. https://doi.org/10.1063/1.5062682

Hittini, B. Y., Shibeika, A. I. (2019). Construction waste management in UAE: An exploratory study. WIT transactions on ecology and the environment, 238, 679-686 https://doi.org/10.2495/SC190581 
Rwanda Journal of Engineering, Science, Technology and Environment, Volume 4, Issue 1, June 2021

eISSN: 2617-233X | print ISSN: 2617-2321

Hobbs, G., Adams, K. (2017). Reuse of building products and materials - barriers and opportunities. International HISER Conference on Advances in Recycling and Management of Construction and Demolition Waste

Holm, F. H. (1998). Ad hoc committee on sustainable building, Norwegian building research institute, Blinderm

Ikau, R., Joseph, C., Tawie, R. (2016). Factors influencing waste generation in the construction industry in Malaysia. Procedia - social and behavioral sciences, 234, 11-18 https://doi.org/10.1016/j.sbspro.2016.10.213

McDonald, B., Smithers, M. (1998). Implementing a waste management plan during the construction phase of a project: a case study, Construction management \& Economics, 16.1, $71-78$

Memon, N. A., Akram, M., Khahro, S. H., Nicolae, P. (2015). Reduction of construction waste at site. 3rd International Conference on Energy and Environment: Innovation, Research \& Sustainability (ICEE'15), 3-8

Oke A., Aghimien Douglas, Aigbavboa C., Madonsela Z. (2019). Environmental sustainability: impact of construction activities. Proceedings of the $11^{\text {th }}$ international conference on construction in the $21^{\text {st }}$ Century, London, United Kingdom

Tam, V. W. Y., Lu, W. (2016). Construction waste management profiles, practices, and performance: A cross-jurisdictional analysis in four countries. Sustainability (Switzerland), 8(2), 1-16 https://doi.org/10.3390/su8020190 